\title{
A Continuous Palynological Record of Forest Clearing at Rano Kao (Easter Island, SE Pacific) During the Last Millennium: Preliminary Report
}

\author{
Irantzu Seco ${ }^{1}$, Valentí Rull ${ }^{1}$, $*$, Encarni Montoya ${ }^{1}{ }^{1}$, Núria Cañellas-Boltà ${ }^{1}$, Santiago Giralt ${ }^{1}$, \\ Olga Margalef ${ }^{2,3}$, Sergi Pla-Rabes ${ }^{2}$, William J. D'Andrea ${ }^{4}$, Raymond S. Bradley ${ }^{5}{ }^{\circ}$ and \\ Alberto Sáez ${ }^{6}$ \\ 1 Institute of Earth Sciences Jaume Almera (ICTJA-CSIC), 08028 Barcelona, Spain; \\ irantzu.seco@gmail.com (I.S.); emontoya@ictja.csic.es (E.M.); ncanellas@ictja.csic.es (N.C.-B.); \\ sgiralt@ictja.csic.es (S.G.) \\ 2 Ecological Research Center and Forestry Applications (CREAF), 08193 Cerdanyola del Vallès, Spain; \\ omargalefgeo@gmail.com (O.M.); sergiplarabes@gmail.com (S.P.-R.) \\ 3 Global Ecological Unit CREAF-CSIC-UAB, 08193 Bellaterra, Spain \\ 4 Lamont-Doherty Earth Observatory (LDEO), Columbia University, Palisades, NY 10964, USA; \\ dandrea@ldeo.columbia.edu \\ 5 Climate System Research Center, Department of Geoscience, University of Massachusetts, Amherst, \\ MA 01003-9297, USA; rbradley@geo.umass.edu \\ 6 Department of Earth and Ocean Dynamics, Universitat de Barcelona, 08028 Barcelona, Spain; a.saez@ub.edu \\ * Correspondence: vrull@ictja.csic.es
}

Received: 24 May 2019; Accepted: 19 June 2019; Published: 21 June 2019

\begin{abstract}
Easter Island (Rapa Nui) deforestation has traditionally been viewed as a single event, synchronous in time and space across the island and caused by Polynesian settlers. However, recent studies have challenged this idea, introducing the concept of spatiotemporal heterogeneity and suggesting a role for climate change. This paper presents a continuous paleovegetation record of the last millennium ( $\sim 960$ to $\sim 1710 \mathrm{CE}$ ), based on palynological analysis of a core from Lake Kao. During this time interval, deforestation was gradual, with three main pulses at $1070 \mathrm{CE}, \sim 1410 \mathrm{CE}$, and $\sim 1600 \mathrm{CE}$, likely driven by drought, anthropogenic practices (mostly fire), or the coupling of both. Some forest regeneration trends have been documented after the first and the second deforestation pulses. Forests were totally removed by $1600 \mathrm{CE}$, coinciding with the full permanent human settlement of the Kao area. Comparison with other continuous palynological records available for the last millennium (Aroi marsh and Lake Raraku) confirms that forest clearing was heterogeneous in time and space, rather than synchronous island-wide.
\end{abstract}

Keywords: charcoal; climate change; deforestation; drought; fire; human disturbance; last millennium; non-pollen palynomorphs; pollen analysis; Rapa Nui

\section{Introduction}

The deforestation of Easter Island (Rapa Nui) was considered for a long time as an abrupt and island-wide event due to the overexploitation of natural resources by the first Polynesian settlers, who were assumed to have caused their own cultural collapse after their arrival on the island, which different authors situated between $800 \mathrm{CE}$ and $1200 \mathrm{CE}$ [1,2]. However, recent paleoecological investigations have challenged this view by suggesting that deforestation was gradual and heterogeneous in time and space across the island, and that the ancient Rapanui civilization was resilient to deforestation [3]. It has been proposed that this discrepancy was related with the occurrence of a millennial-scale sedimentary 
gap in the first palynological studies [4,5], which hid the landscape changes of the last millennia [6]. Recent detailed litho- and chronostratigraphic studies of the Easter Island sedimentary basins have demonstrated the complexity of sedimentary patterns and the occurrence of numerous inconsistencies (notably stratigraphic gaps and age inversions) that complicate paleoecological reconstructions $[7,8]$. Therefore, a careful selection of the coring sites based on the known sedimentary patterns is fundamental for obtaining reliable paleoecological records. New coring campaigns developed during the last decade, with emphasis on the more recent times, have yielded continuous (gap-free) and chronologically coherent paleovegetation records (without age inversions) for Lake Raraku and the Aroi marsh, as shown in Figure 1, two of the three Easter Island sedimentary basins suitable for paleoecological research $[9,10]$. The other sedimentary basin that would be useful for this purpose, Lake Kao (or Kau), remained problematical due to gaps and frequent age inversions that prevented the development of reliable age-depth models [11-13]. A single continuous and chronologically coherent record exists for Lake Kao covering the last millennium [14] but pollen analyses of this sequence have not yet been published. Here we present the pollen analysis of another continuous sequence from Lake Kao encompassing the last millennium [3]. Results are considered preliminary as resolution can be increased and some low abundance pollen and spore types still lack identification. However, deforestation trends are already clearly visible and can be compared with other gap-free and chronologically reliable records of similar resolution from Raraku and Aroi.
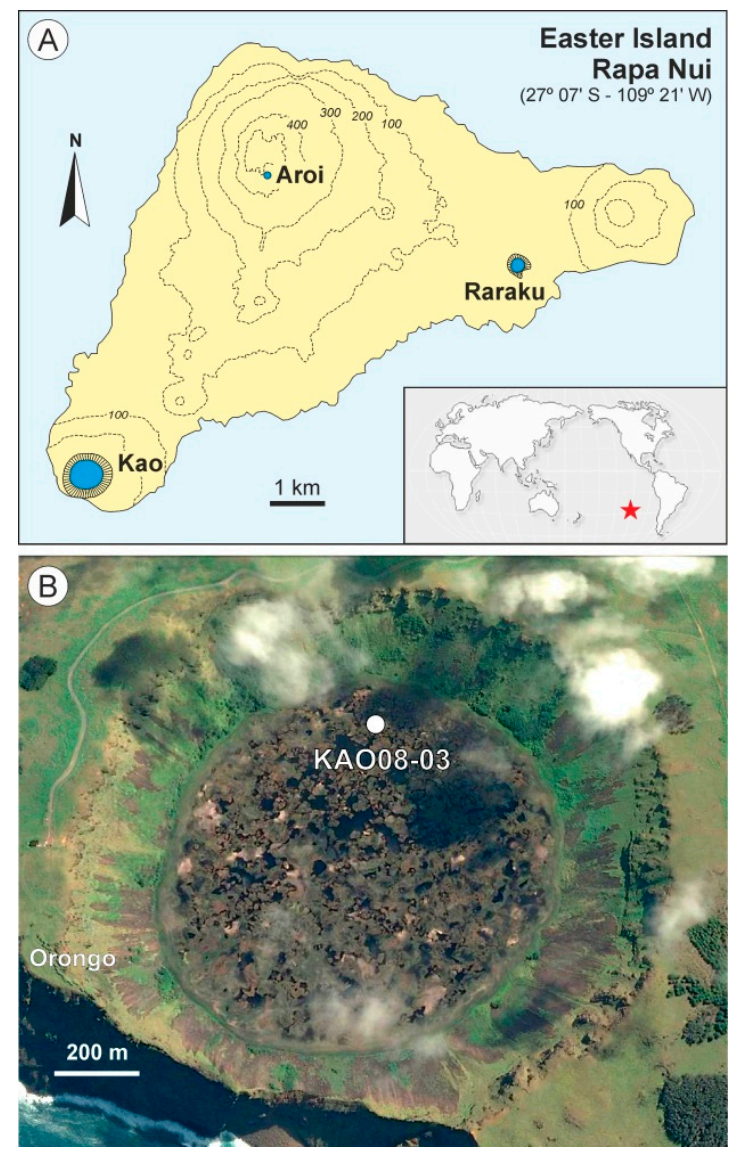

Figure 1. Location map. (A) Sketch-map of Easter Island showing the three paleoecological sites (Aroi, Kao, and Raraku), indicated by blue areas; (B) Google Earth image of Lake Kao showing the coring site (white dot) and the ancient ceremonial village of Orongo.

\section{Materials and Methods}

Lake Kao ( 1250 m diameter and $\sim 10 \mathrm{~m}$ depth) is the largest permanent freshwater body of Easter Island and is located within the Kao volcanic crater, in the southwestern corner of the island, at $110 \mathrm{~m}$ 
elevation, as shown in Figure 1. The surface of this lake is a mosaic of open waters and peat-forming floating mats dominated by Scirpus californicus (Cyperaceae) and Polygonum acuminatum (Polygonaceae). A $220 \mathrm{~cm}$ depth peat core (KAO08-03) was retrieved from this floating mat with a Russian corer, at the northern side of the lake ( $27^{\circ} 10^{\prime} 57.526^{\prime \prime}$ S $\left.-109^{\circ} 26^{\prime} 7.591^{\prime \prime}\right)$, as shown in Figure 1. Nine samples were taken for radiocarbon dating, which was performed at the Radiochronology Lab of the Université Laval (Canada). The age-depth model was carried out using the smooth-spline option in the Clam 2.2 software [15]. Samples for pollen analysis were processed at the ICTJA Laboratory of Paleoecology with standard palynological methods, including $\mathrm{KOH}, \mathrm{Na}_{4} \mathrm{P}_{2} \mathrm{O}_{4}, \mathrm{HCL}$, and $\mathrm{HF}$ digestions, acetolysis, and mounting in glycerin-jelly [16]. Lycopodium tablets were added before treatment. Counting procedures followed [17]. The diagram was plotted with psimpoll 4.27 and pollen zones were obtained using the OSIC (optimal splitting by information content) method, which chooses the zonation that minimizes the variance of the data set as a whole based on the total information content [18]. The interpretation of these zones was based on previous knowledge about pollen-vegetation relationships on Easter Island, with the addition of some indicator non-pollen palynomorphs (NPPs) that were not analyzed in former investigations. Among these NPPs, the most important are fungal spores from genera such as Sporormiella, Byssothecium, Gelasinospora, and Glomus. Sporormiella is a coprophilous fungi growing in the dung of domestic vertebrates and is thus commonly used as an indicator of human presence [19]. Byssothecium is a saprobe or weak parasite on woody and other plant remain substrates, whereas Gelasinospora prefers dry conditions with charred material [20]. Glomus, a mycorrhizal fungus living in forest soils is commonly considered as an indicator of increased erosion rates [21]. Microcharcoal particle concentration, expressed in particles $>5 \mu \mathrm{m} / \mathrm{g}$, was used as a proxy for fire.

\section{Results}

Radiocarbon ages are shown in Table 1 and the best-fit age-depth model is displayed in Figure 2. According to this model, the sequence encompasses roughly the last millennium, except the last 2-3 centuries ( $\sim 1020 \mathrm{cal}$ yr BP to ca. $\sim 240 \mathrm{cal}$ yr BP or $\sim 930 \mathrm{CE}$ to $\sim 1710 \mathrm{CE})$. The sampling resolution was multidecadal ( $\sim 36$ years/sample). The average model error was $5.3 \%$ (range: $4.0 \%$ to $11.5 \%$ ). Average accumulation rates were $3.6 \mathrm{~mm} /$ year (range: $2.1 \mathrm{~mm} /$ year to $4.6 \mathrm{~mm} /$ year), with lower values in the uppermost part of the sequence, higher values in the intermediate part, and medium values in the basal part. The pollen diagram was subdivided into four pollen zones, as shown in Figure 3, from I to IV, which are described in chronological order.

Table 1. Results of radiocarbon dating carried out at the Radiochronology Lab of the Université Laval (Canada). All samples were pollen residues. The sample with an asterisk was not used in the age-depth model.

\begin{tabular}{cccccc}
\hline Core Sample & Lab Code & Depth $\mathbf{( c m )}$ & ${ }^{14}$ C yr BP & Cal yr BP & Range (2) \\
\hline KAO3-1-24 & ULA-5790 & 106 & $305 \pm 15$ & 312 & $289-327$ \\
\hline KAO3-1-43 & ULA-5792 & 125 & $290 \pm 15$ & 304 & $283-323$ \\
\hline KAO3-2-39 & ULA-5789 & 141 & $355 \pm 20$ & 392 & $350-452$ \\
\hline KAO3-2-20 & ULA-5791 & 160 & $470 \pm 20$ & 499 & $468-516$ \\
\hline KAO3-6-15 & ULA-5872 & 196 & $695 \pm 15$ & 597 & $563-658$ \\
\hline KAO3-6-35 & ULA-5821 & 216 & $885 \pm 20$ & 748 & $720-791$ \\
\hline KAO3-7-16 & ULA-5874 & 247 & $5060 \pm 20$ & 5755 & $5658-5891$ \\
\hline KAO3-7-40 & ULA-5817 & 271 & $1060 \pm 20$ & 934 & $906-962$ \\
\hline KAO3-8-12 & ULA-5873 & 297 & $1165 \pm 15$ & 1017 & $968-1059$ \\
\hline
\end{tabular}




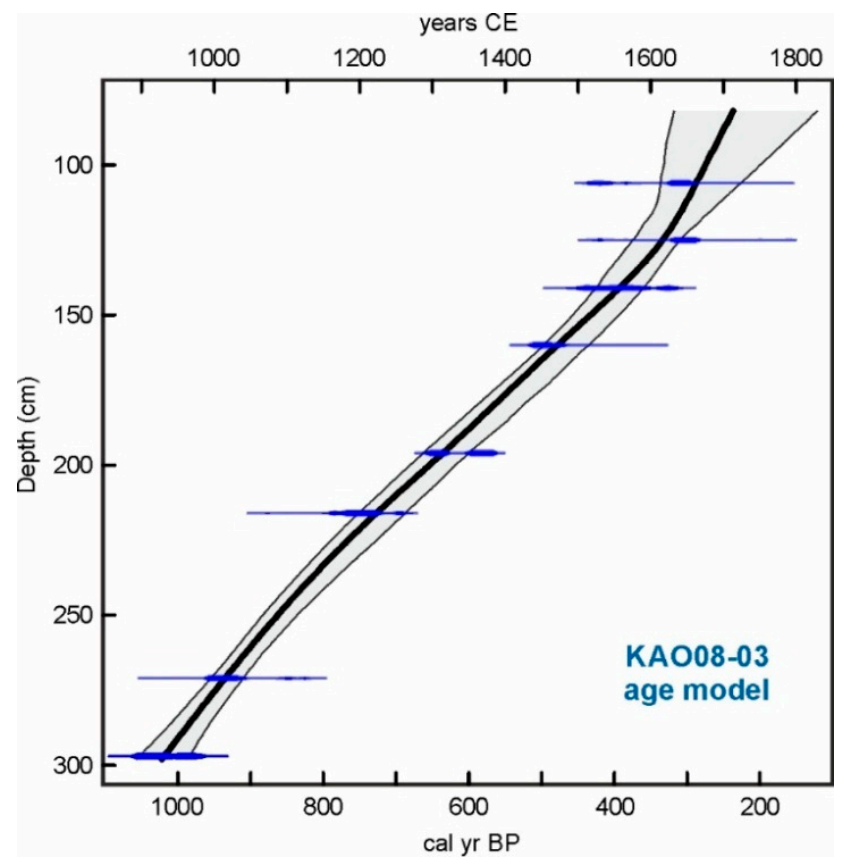

Figure 2. Age-depth model of core KAO08-03 using the radiocarbon dates of Table 1 and the smooth-spline option.

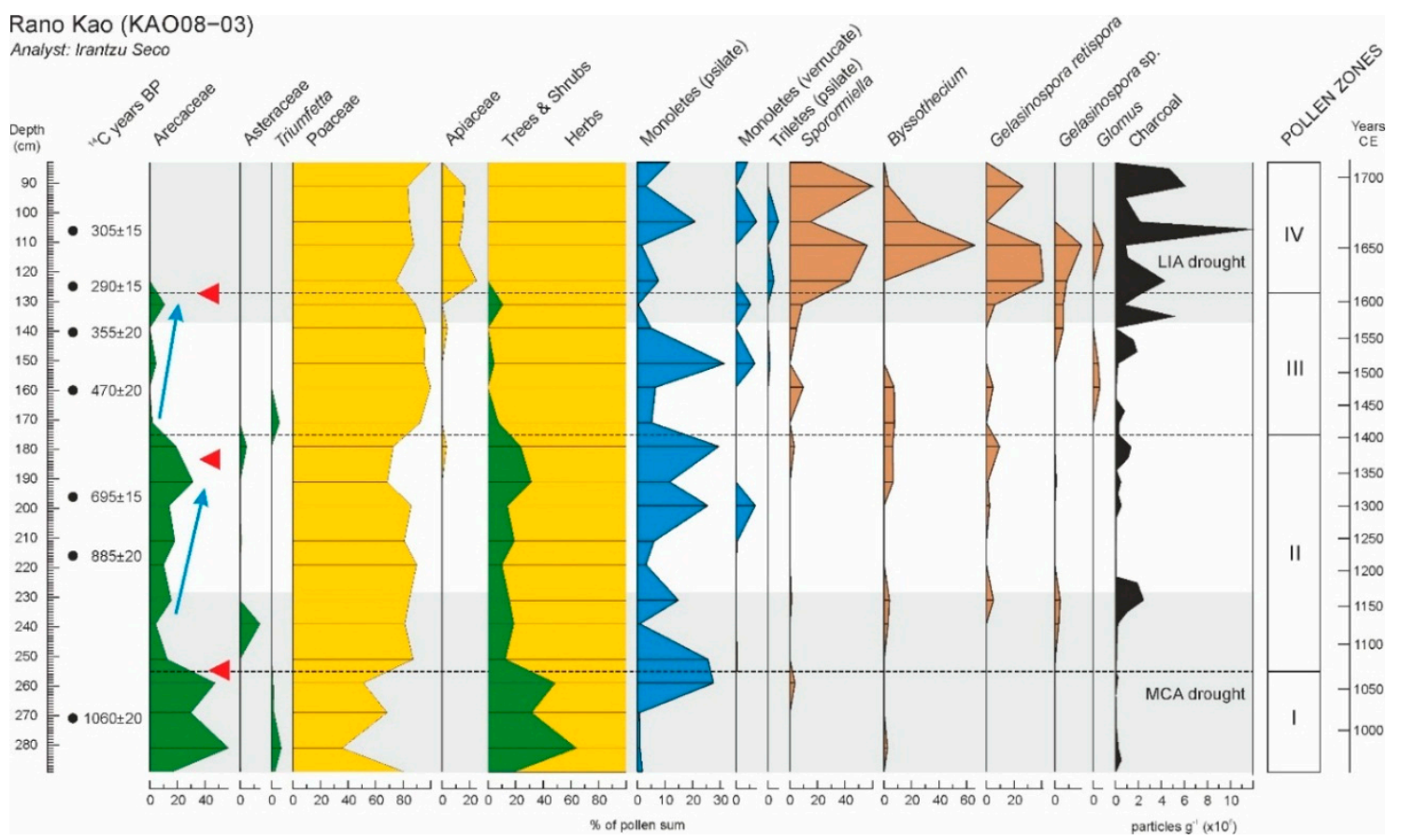

Figure 3. Pollen diagram of core KAO08-03. Gray bands indicate the droughts that desiccated Lake Raraku [9]. Deforestation pulses are indicated as red arrows in the Arecaceae curve. Blue arrows indicate forest regeneration trends.

Pollen Zone I (289-255 cm; 993-881 cal yr BP; 957-1069 CE). This zone is co-dominated by palms and grasses, suggesting an open palm woodland with Triumfetta (Tiliaceae) shrubs in the understory. Ferns started to be abundant at the end of the zone. Indicator NPPs were still absent, with only scattered occurrences of Sporormiella and Byssothecium. Charcoal is present but in very low amounts. The whole picture suggests a dispersed human presence with a very low ecological impact. 
Pollen Zone II (255-175 cm; 881-544 cal yr BP; 1069-1406 CE). This zone begins with a rapid and significant palm forest decline, with a minimum at $\sim 1100 \mathrm{CE}$, that turned the Kao vegetation into a grassland with scattered palm trees. This conspicuous shift occurred in the middle of a Medieval Climatic Anomaly (MCA) climatic drought that desiccated the shallower Lake Raraku [9] and is not associated with a coeval increase in indicators of human presence (Sporormiella, charcoal), which suggests that climate may have been the main driver for the forest decline. A fire peak occurred at 1150-1200 CE but this did not seem to affect the trend of forest regeneration, possibly favored by a wetter climate [9]. This regeneration culminated at $~ 1350 \mathrm{CE}$, when a new forest retraction took place, this time coeval with small increases of Sporormiella and fire, suggesting more intense human activity than in former times.

Pollen Zone III (175-127 cm; 544-340 cal yr BP; 1406-1610 CE). At the beginning of this zone, palm pollen almost disappeared, and the landscape became almost entirely herbaceous. Indicators of human presence (Sporormiella, charcoal) slightly increased and fungi associated with dead wood and charred plant material (Byssothecium, Gelasinospora) followed a similar trend, supporting anthropogenic forest clearing and the corresponding accumulation of degraded and burned wood and other plant materials. Minimum forest values at $1470 \mathrm{CE}$ coincided with an increase of erosion indicators (Glomus). A new forest regeneration trend can be observed, culminating at the end of the zone, although this is less intense than in the former pollen zone. A significant increase in fire indicators and coprophilous fungi (Sporormiella) at the end of the zone (from 1550 CE onwards) suggests that forest regeneration was interrupted by human occupation of the Kao catchment. The onset of another drought during the Little Ice Age (LIA) [9] would have contributed to fire exacerbation.

Pollen Zone IV (127-83 cm; 340-239 cal yr BP; 1610-1711 CE). The Kao area was already devoid of forests, which were replaced by extensive grassland meadows, with the addition of an unknown Apiaceae. Human settlement increased abruptly, as indicated by the dramatic increase of fires, coprophilous fungi (Sporormiella), and saprophytic fungi (Byssothecium and Gelasinospora). This coincided with the maximum development of a LIA drought recorded at Lake Raraku [9], which suggests that climate could also have had a role by favoring biomass flammability and fire expansion. Archaeological evidence indicates that the ceremonial village of Orongo, situated on the SW of the Kao crater, as shown in Figure 1, was founded by 1600 CE [22], which is consistent with an eventual permanent human occupation of the Kao catchment and the development of intensive terrace cultivation practices on the shores of the lake [13].

\section{Preliminary Conclusions}

Based on the above results, some preliminary conclusions may be advanced pending further high-resolution studies. However, the main trends of deforestation and landscape shift are not expected to undergo significant changes.

- During the last millennium ( 960 CE onwards), the Lake Kao catchment was progressively deforested, with the total disappearance of forests by $\sim 1600 \mathrm{CE}$.

- Forest clearing was gradual but spiked with three major acceleration pulses at $\sim 1070 \mathrm{CE}, \sim 1410 \mathrm{CE}$, and $1600 \mathrm{CE}$.

- Forest regeneration was observed after the $\sim 1070 \mathrm{CE}$ pulse and, to a minor extent, after the $\sim 1410$ CE acceleration.

- Using the pollen percentage as a proxy for forest cover, the general deforestation trend progressed at a rate of -10 forest pollen \%/century, whereas accelerations occurred at rates of $-30 \%$ to $-50 \% /$ century.

- Both climatic (drought) and anthropogenic (mostly fire) drivers, as well as their coupled action, seem to have had a role in the acceleration of forest clearance.

- Total deforestation coincided with the permanent human settlement of the lake catchment, coinciding with the foundation of the ceremonial village of Orongo, around $1600 \mathrm{CE}$. 


\section{Comparison with Previous Records}

The Kao deforestation timing and rates were different from those observed in Lake Raraku and the Aroi marsh, as shown in Table 2, confirming that forest clearing was heterogeneous in time and space across the island, contradicting the earlier hypothesis of a single, abrupt, and island-wide event. These differences are consistent with previous observations of spatiotemporal differences in land use across the island [23]. The Kao deforestation timing is also consistent with the hypothesis of intra-island population migration and reorganization as a consequence of the coupled action of the LIA drought and anthropogenic deforestation [3]. According to archaeological evidence, Lake Raraku and its surroundings was the center of the ancient Rapanui civilization, based on the cult of the megalithic anthropomorphic statues known as moai, which were carved from the tuff that forms the Raraku crater. At some point, a cultural revolution took place and the main center of Rapanui moved to Orongo, on the edge of the Kao crater. This then became the center of a new cult (the Birdman cult) involving a profound social, religious, and political reorganization [22]. The earlier date proposed for this cultural shift is $1600 \mathrm{CE}$, when Orongo was founded. According to the intra-island migration hypothesis [3,24], the desiccation of Lake Raraku between $\sim 1570 \mathrm{CE}$ and $1720 \mathrm{CE}$, together with the full forest removal of this catchment, had occurred by $1530 \mathrm{CE}$, and would have turned the site into a badland unable to support human life and the activities required for the Moai cult. By then, Lake Kao was likely the only permanent freshwater source on the island and, hence, the most suitable site to sustain human life. Therefore, a migration of the cultural center from Raraku to Kao seems a plausible explanation and is supported by the chronological coincidence between the foundation of Orongo (1600 CE), as shown by archaeological evidence [22], and the full human occupation of the Kao catchment, as documented in this paleoecological study. Further paleoecological research based on biomarkers, as indicators of climate change and human presence and activities, is in progress.

Table 2. Comparison of deforestation timing and rates in the three Easter Island sedimentary basins, based on continuous and chronologically coherent pollen records for the last millennia. Rates are in \% of pollen palm decrease per century.

\begin{tabular}{cccccc}
\hline Site & Onset & End & Time (years) & Rates (\%) & References \\
\hline Aroi & $1520 \mathrm{CE}$ & $1620 \mathrm{CE}$ & 100 & -73 & Rull et al. [10] \\
\hline Kao & $1070 \mathrm{CE}$ & $1600 \mathrm{CE}$ & 530 & -10 & This paper \\
\hline Raraku & $450 \mathrm{BCE}$ & $1530 \mathrm{CE}$ & 1980 & -7 & Cañellas-Boltà et al. [9] \\
\hline
\end{tabular}

Author Contributions: Conceptualization, V.R.; data curation, V.R.; formal analysis, I.S. and E.M.; funding acquisition, V.R. and A.S.; investigation, I.S., V.R., E.M., N.C.-B., S.G., O.M., S.P.-R., W.J.D., R.S.B. and A.S.; methodology, I.S., V.R., E.M., N.C.-B. and A.S; software, E.M.; supervision, V.R., E.M. and A.S.; validation, V.R. and E.M.; visualization, I.S., V.R. and E.M.; writing - original draft, V.R.; writing - review \& editing, E.M., N.C.-B., S.G., O.M., S.P.-R., W.J.D., R.S.B. and A.S.; methodology, I.S., V.R., E.M., N.C.-B. and A.S.

Funding: This research was funded by projects LAVOLTER (CGL2004-00683) and GEOBILA (CGL2007-60932/BTE) from the Spanish Ministry of Education and Science.

Acknowledgments: Fieldwork permits were granted by the National Forestry Corporation of Chile (CONAF).

Conflicts of Interest: The authors declare no conflict of interest.

\section{References}

1. Flenley, J.R.; Bahn, P.G. The Enigmas of Easter Island; Oxford University Press: Oxford, UK, 2003.

2. Diamond, J. Collapse: How Societies Choose to Fail or Survive; Allen Lane: London, UK, 2005.

3. Rull, V.; Montoya, E.; Seco, I.; Cañellas-Boltà, N.; Giralt, S.; Margalef, O.; Pla-Rabes, S.; D’Andrea, W.; Bradley, R.; Sáez, A. CLAFS, a holistic climatic-ecological anthropogenic hypothesis on Easter Island's deforestation and cultural change: Proposals and testing prospects. Front. Ecol. Evol. 2018, 6, 32. [CrossRef]

4. Flenley, J.R.; King, S. Late Quaternary pollen records from Easter Island. Nature 1984, 307, 47-50. [CrossRef] 
5. Flenley, J.R.; King, A.S.M.; Jackson, J.; Chew, C. The Late Quaternary vegetational and climatic history of Easter Island. J. Quat. Sci. 1991, 6, 85-115. [CrossRef]

6. Rull, V.; Cañellas-Boltà, N.; Sáez, A.; Margalef, O.; Bao, R.; Pla-Rabes, S.; Valero-Garcés, B.; Giralt, S. Challenging Easter Island's collapse: The need for interdisciplinary synergies. Front. Ecol. Evol. 2013, 1, 3. [CrossRef]

7. Sáez, A.; Valero-Garcés, B.L.; Giralt, S.; Moreno, A.; Bao, R.; Pueyo, J.J.; Hernández, A.; Casas, D. Glacial to Holocene climate changes in the SE Pacific. The Raraku Lake sedimentary record (Easter Island, $\left.27^{\circ} \mathrm{S}\right)$. Quat. Sci. Rev. 2009, 28, 2743-2759. [CrossRef]

8. Margalef, O.; Cañellas-Boltà, N.; Pla-Rabes, S.; Giralt, S.; Pueyo, J.J.; Joosten, H.; Rull, V.; Buchaca, T.; Hernández, A.; Valero-Garcés, B.L.; et al. A 70,000 year multiproxy record of climatic and environmental change from Rano Aroi peatland (Easter Island). Glob. Planet. Change 2013, 108, 72-84. [CrossRef]

9. Cañellas-Boltà, N.; Rull, V.; Sáez, A.; Margalef, O.; Bao, R.; Pla-Rabes, S.; Blaauw, M.; Valero-Garcés, B.; Giralt, S. Vegetation changes and human settlement of Easter Island during the last millennia: A multiproxy study of the Lake Raraku sediments. Quat. Sci. Rev. 2013, 72, 36-48. [CrossRef]

10. Rull, V.; Cañellas-Boltà, N.; Margalef, O.; Sáez, A.; Pla-Rabes, S.; Giralt, S. Late Holocene vegetation dynamics and deforestation in Rano Aroi: Implications for Easter Island's ecological and cultural history. Quat. Sci. Rev. 2015, 126, 219-226. [CrossRef]

11. Butler, K.; Prior, C.A.; Flenley, J.R. Anomalous radiocarbon datesfrom Easter Island. Radiocarbon 2004, 46, 395-420. [CrossRef]

12. Butler, K.R.; Flenley, J.R. The Rano Kau 2 pollen diagram: Palaeoecology revealed. Rapa Nui J. 2010, $24,5-10$.

13. Horrocks, M.; Baisden, W.T.; Nieuwoudt, M.K.; Flenley, J.; Feek, D.; González Nualart, L.; Haoa-Cardinali, S.; Edmunds Gorman, T. Microfossils of Polynesian cultigens in lake sediment cores from Rao Kau, Easter Island. J. Paleolimnol. 2012, 47, 185-204. [CrossRef]

14. Gossen, C. Report: The mystery lies in the Scirpus. Rapa Nui J. 2007, 21, 105-110.

15. Blaauw, M. Methods and code for "classical" age-modelling of radiocarbon sequences. Quat. Geochronol. 2010, 5, 512-518. [CrossRef]

16. Bennett, K.D.; Willis, K.J. Pollen. In Tracking Environmental Changes Using Lake Sediments. Vol. 3: Terrestrial, Algal and Siliceous Indicators; Smol, J.P., Birks, H.J.B., Last, W.M., Eds.; Kluwer Academic Publishers: Dordrecht, The Netherlands, 2001; pp. 5-32.

17. Rull, V. A note on pollen counting in paleoecology. Pollen Spores 1987, 29, 471-480.

18. Bennett, K.D. Determination of the number of zones in a biostratigraphical sequence. New Phytol. 1996, 132, 155-170. [CrossRef]

19. Van Geel, B.; Buurman, J.; Brinkkemper, O.; Schelvis, J.; Aptroot, A.; van Reenen, G.; Hakbijl, T. Environmetal reconstruction of a Roman Period settlement site in Uitgeest (The Netherlands), with special reference to coprophilous fungi. J. Archaeol. Sci. 2003, 30, 873-883. [CrossRef]

20. Van Geel, B.; Aptroot, A. Fossil ascomycetes in Quaternary depoists. Nova Hedwigia 2006, 82, $313-329$. [CrossRef]

21. Anderson, R.S.; Homola, R.L.; Davis, R.B.; Jacobosn, G.L. Fossil remains of the mycorrhizal fungal Glomus fasciculatum complex in postglacial lake sediments from Maine. Can. J. Bot. 1984, 62, 2325-2328. [CrossRef]

22. Robinson, T.; Stevenson, C.M. The cult of the Birdman: Religious change at 'Orongo, Rapa Nui (Easter Island). J. Pacif. Archaeol. 2017, 8, 88-102.

23. Stevenson, C.M.; Puleston, C.O.; Vitousek, P.M.; Chadwick, O.A.; Haoa, S.; Ladefoged, T.N. Variation in Rapa Nui (Easter Island) land use indicates production and population peaks prior to European contact. Proc. Natl. Acad. Sci. USA 2015, 112, 1025-1030. [CrossRef]

24. Rull, V. Natural and anthropogenic drivers of cultural change at Easter Island: Review and new insights. Quat. Sci. Rev. 2016, 150, 31-41. [CrossRef]

(C) 2019 by the authors. Licensee MDPI, Basel, Switzerland. This article is an open access article distributed under the terms and conditions of the Creative Commons Attribution (CC BY) license (http://creativecommons.org/licenses/by/4.0/). 